in the Geological Department of Liverpool University from the time of its establishment in 1916, and for a brief period during the War lectured there in the absence of the Professor. In July, 1929, the honorary degree of M.Sc. was conferred upon him by the University. Towards the equipment of the new departmental building of Geology opened in October last, he made a generous contribution.

For some years he acted as honorary director of the Liverpool and District Regional Survey Association, and his interest in its work led him to compile his well-known book on "The Wirral Peninsula-an Outline Regional Survey", as well as to write many papers of value to the student of the history and progress of Wirral. All his work was characterized by painstaking care and high conscientiousness, and he was esteemed by all who knew him.

T. A. JoNes.

\title{
CORRESPONDENCE.
}

\section{IRON-RICH CORDIERITE.}

Sin,-Now that the composition of cordierite is once more the subject of discussion (H. H. Read, Geol. MaG., Vol. LXVI, 1929, p. 547) it may not be out of place to refer to a recent study by Ramdohr of the iron-rich contact rocks around the Brocken massif (Neues Jahrbuch für Min., etc., 1927, A. p. 333). Ramdohr describes cordierite rocks resulting from the thermal metamorphism of ironore rocks, particularly mineralized tuffs, the cordierite being associated with an iron-olivine and a hercynite spinel. The bulk analysis of the rocks (e.g., one from Spitzenberg-Klippen, op. cit., p. 377) is sufficient to show that these cordierites may be added to the list of iron-rich cordierites compiled by Dr. Read. The interest of the contact-altered iron-ore rocks of the Harz, however, lies rather in the nature of the assemblages developed. A fayalitehercynite-cordierite hornfels is an assemblage described for the first time. This assemblage is one of especial interest. In a note on the paragenesis of the minerals of the system $\mathrm{MgO}-\mathrm{Al}_{2} \mathrm{O}_{3}-\mathrm{SiO}_{2}$ (GEOL. MAG., Vol. LX, 1923, p. 101), I observed that whilst in artificial melts the association cordierite-forsterite occurred, amongst natural rocks the pair was represented by a spinel-enstatite assemblage. A reversible transformation spinel + enstatite $\rightleftarrows$ cordierite + forsterite was suggested, the left hand pair representing the lowtemperature association under the conditions of metamorphism. In the corresponding system $\mathrm{FeO}-\mathrm{Al}_{2} \mathrm{O}_{3}-\mathrm{SiO}_{2}$, however, it seems clear that the cordierite-fayalite assemblage is the stable association under similar conditions. The field of existence of iron-orthopyroxene is unknown and is clearly not realized among the contact rocks of the Harz, for fayalite-quartz assemblages are recorded by Ramdohr. At lower temperatures in the presence of water these latter minerals react to give an amphibole (iron-anthophyllite or 
gruenerite) while the fayalite-cordierite pair pass to an aluminous gedrite. Rankin and Merwin, in their study of the system, MgO$\mathrm{Al}_{2} \mathrm{O}_{3}-\mathrm{SiO}_{2}$, expressed the view that the introduction of iron into the system might lead to the disappearance of the cordierite field, a suggestion which is now the less convincing. The many pressing petrological problems associated with equilibria in iron-containing silicate systems-of which this is one-would doubtless soon find their solution if some advance could be made in overcoming the great experimental difficulties associated with the investigation of these systems.

\section{E. Tilley.}

\section{A NOTE ON THE HOJYWELL SHALES.}

SIR,-The report in your issue of January last of the paper by Messrs. W. Lloyd and R. C. B. Jones on "The Upper Carboniferous of Flintshire", read before the Manchester Geological Association on 12th November last, shows that valuable results have been obtained, and the publication of the full paper will be awaited with interest.

The identification by Dr. J. W. Jackson of Posidonomya corrugata, the fossil previously referred in error by me and others to $P$. becheri, from beds resting on the chert near Holywell, shows that in that district the $P$ beds have been cut out.

I showed in a former paper (this Magazine, Vol. 64, 1927, p. 252) that on the northern fringe of the chert outcrop the lowest shales resting on the chert are of $P$ age, with undoubted $P$. becheri. At Holywell, seven miles to the south-east, it now seems clear that the lowest shales are of low $E$ age. Still further to the south-east, in the neighbourhood of Hope, the lowest shales (fide Lloyd and Jones) are of upper $E$ age, with Eumorphoceras bisulcatum.

It seems clear, therefore, that there is a definite overlapping of the shales from north-west to south-east and the occurrence of $P$. corrugata at Holywell does not in that case indicate (as suggested in the report) any change in the stratigraphical position of the Chert-beds. These beds are seen resting directly on the Carboniferous limestone at many points from near Prestatyn on the north of the Chert outcrop to Moel-y-Gaer on the south, including the intermediate Holywell district.

The transgression is still further emphasized at Nant-y-Figillt, south of Moel-y-Gaer, where the authors report $G$. cancellatum and $R$. reticulatum, mut. $\gamma$, a short distance above the limestone.

I venture to think that there can be no doubt that the Chert-beds are of Lower Carboniferous age, and, judging from the abstract of their paper, the authors' valuable work shows that the Holywell Shales rest upon them unconformably and overstep them on the south.

H. C. Sargent. 